\title{
The Policy Feasibility Analysis of Paid Father- specific Parental Leave Policy in China Discussion from the Perspective of Policy Comparison
}

\author{
Xiwen Huang ${ }^{1, *}$ \\ ${ }^{1}$ School of Foreign Languages, Southeast University, Nanjing, Jiangsu 210000, China \\ *Corresponding author.Email: jessica418@126.com
}

\begin{abstract}
As the world population enters the stage of modern population growth, many countries are facing the risk of declining fertility rates and increasing aging trends in recent years. Among the family policies around the world, father-specific parental leave or home care policy has been proved to be of great significance in promoting gender equity and raising the national fertility rate among some European countries. The paper examines the feasibility of enacting the Paid Father-specific Parental Leave Policy in China, based on the previous practices taken in Sweden, the United States, and Japan in the past few years from the perspective of policy comparison. In the first part, this paper makes an in-depth comparison and analysis of the family policies in the four countries from several dimensions, including beneficiary groups, financial support and the length of holidays. In the latter part, the paper analyzes the advantages and disadvantages of the policies of Sweden, the United States and Japan, and the author will provides suggestions for the implementation of parental leave policies in China. The conclusion drawn from the paper is that the Chinese government should provide both direct and indirect support for parents, especially for career women. Supporting policies should emphasize father's participation in childcare, and the government should also consider other cooperative parenting policies as a whole.
\end{abstract}

Keywords: Paid Father-specific Parental Leave, Family policy, Gender equity, Policy comparison.

\section{INTRODUCTION}

Like most developed countries in Europe and North America, China has much lower fertility rates and natural growth rates than in the past few decades. The 1980s "one-child" policy has alleviated the crisis of overpopulation, but brought new problems. According to the 2020 China National Bureau of Statistics [1], after the implementation of the "two-child" policies in the 2010 s, the number of newly-born population in China continued to decline after only a brief increase within one year of the promulgation of the policy. The exorbitant child-bearing costs and the absence of appropriate family policy deprived people of fertility desires, especially for career women. The difficulties of keeping a balance between career development and family plan made it even harder for women to give birth to a child.
There have been several parenting policies in high-income, developed countries that contributed to relieving women from the family burden, closing gender gaps and promoting fertility, among which the father-specific paid parental leave policies are considered to be one of the most effective. As the leave supplementary to maternity leave or paternity leave, the parental leave refers to a holiday during which either parent leaves work for a longer period to take care of the child with some income support. In this sense, by encouraging fathers' involvement in child care, the father-specific parental and home care leave policy is not only beneficial to growth and development of children, but eases the employment disadvantage of women due to pregnancy, combining a higher fertility with higher female labor force participation [2].

However, considering the differences in the economic development in different countries, it is 
obvious that not feasible for the governments to set up standardized policies. To make a deeper analysis, this paper is divided into two main parts. In the first part, the parental leave policies and the implementation results in some high income countries are specifically stated through policy comparison. In the second part, the author will analyze the development and difficulties of similar policies in China through the employment and fertility data of female labor force.

\section{OVERVIEW OF PAID FATHER- SPECIFIC PARENTAL LEAVE POLICIES IN HIGH-INCOME COUNTRIES}

At the end of the 20th century, some European countries started to take the leading policies in encouraging fathers' involvement in child care, in order to balance the gender differences caused by childbearing, and effectively promote the nations' fertility. Data from OECD Family Database showed that several high-income countries in the world have set up parental leave policies that are specifically reserved for fathers (not transferable to mothers), while others set up gender-neutral parental leave policies to encourage fathers to take time off [3]. Due to the different social contexts and cultural factors, the paternal parental leave policies vary considerably across countries.

In this part, the father-specific or gender-neutral parental leave policies of several representative countries are taken as the examples to compare with the current policies of China from many aspects, including the target groups, length, paid, the main sources of financial support, and other factors ("Table 1"). The example includes the direct parenting supported policies provided by the national government (represented by Sweden) and the policy series advocated by governments and other social institutions (represented by the United States). Japan is a government-oriented policy, but it will be hindered by companies in the implementation process. This also reflects the practical difficulties that may be encountered during the implementation of the policy.

Table 1. Comparison between parental leave policy in Sweden, US, Japan and China

\begin{tabular}{|c|c|c|c|c|}
\hline Country & Length & Target Group & Payment & Finance Support Source \\
\hline Sweden & $\begin{array}{l}\text { Parents with joint custody are eligible for } \\
240 \text { days of Parental leave benefit each, with } \\
90 \text { days are reserved for each parent (non- } \\
\text { transferable). Family entitlement. } \\
\text { Fully flexible. It can be divided into full } \\
\text { days, half days, } 1 / 4 \text { days, or one hour. } \\
\text { Parents can take up to } 30 \text { days at the same } \\
\text { time. }\end{array}$ & $\begin{array}{l}\text { Father or Mother } \\
\text { (with specific } \\
\text { availability to each } \\
\text { gender) }\end{array}$ & $\begin{array}{l}\text { Paid. } \\
\text { First } 195 \text { days (each): } 77.6 \% \text { of } \\
\text { earnings up to an earnings } \\
\text { ceiling at SEK } 455004 . \\
\text { Last } 45 \text { days (each): SEK } 180 \\
\text { per day. }\end{array}$ & Government \\
\hline \multirow[t]{3}{*}{ US } & $\begin{array}{l}\text { Family and medical Leave (FMLA): } 12 \\
\text { weeks. Individual entitlement. }\end{array}$ & $\begin{array}{l}\text { Father or Mother } \\
\text { (gender-neutral) }\end{array}$ & Unpaid. & 1 \\
\hline & $\begin{array}{l}\text { Paid Family Leave (PFL): 4-6 weeks (vary in } \\
\text { different states). Family Entitlement. }\end{array}$ & $\begin{array}{l}\text { Father or Mother } \\
\text { (gender-neutral) }\end{array}$ & $\begin{array}{l}\text { Paid. } \\
\text { California: } 55 \% \text { of earnings up } \\
\text { to an earnings ceiling at USD } \\
1075 \text { per week. } \\
\text { New Jersey: } 66 \% \text { of earnings } \\
\text { up to an earnings ceiling at } \\
\text { USD } 595 \text { per week. } \\
\text { Rhode Island: } 60 \% \text { of earnings } \\
\text { up to an earnings ceiling at } \\
\text { USD } 752 \text { per week. }\end{array}$ & Employees \\
\hline & $\begin{array}{l}\text { Early Childhood Education and Care } \\
(E C E C)\end{array}$ & $\begin{array}{l}\text { Children ( 0-5 years } \\
\text { old ) }\end{array}$ & $\begin{array}{l}\text { Unpaid. } \\
\text { Total expenditure accounts for } \\
1.6 \% \text { of US GDP. }\end{array}$ & $\begin{array}{|lrr|}\text { Government } & & \text { (Federal } \\
\text { government } & \text { and } & \text { state } \\
\text { governments) } & & \end{array}$ \\
\hline
\end{tabular}




\begin{tabular}{|c|c|c|c|c|}
\hline Country & Length & Target Group & Payment & Finance Support Source \\
\hline Japan & $\begin{array}{l}\text { - Up to } 52 \text { weeks. Individual entitlement. } \\
\text { - Leave can be taken until a child is } 12 \\
\text { months old. One parent can take their leave } \\
\text { up until the child is } 14 \text { months old if both } \\
\text { parents take some of the leave. }\end{array}$ & $\begin{array}{l}\text { Father or Mother } \\
\text { (gender-neutral, } \\
\text { with no specifi } \\
\text { availability to eac } \\
\text { gender, bu } \\
\text { encourage father } \\
\text { involvement) }\end{array}$ & $\begin{array}{l}\text { Paid. } \\
\text { First } 180 \text { days: } 67 \% \text { of } \\
\text { cearnings, up to an earnings } \\
\text { ceiling of JPY } 447000 \text { with a } \\
\text { tminimum payment of JPY } \\
49647 \text { per month and a } \\
\text { maximum of JPY } 299691 \text { per } \\
\text { month. } \\
\text { Remainder: } 50 \% \text { of earnings, } \\
\text { with a minimum payment of } \\
\text { JPY } 37050 \text { per month and a } \\
\text { maximum of JPY } 223650 \text { per } \\
\text { month. }\end{array}$ & Government \\
\hline China & $\begin{array}{l}\text { No parental leave policy. } \\
\text { Paternity leave: } 7-30 \text { days (vary in } 26 \\
\text { provinces and regions). }\end{array}$ & Father & $100 \%$ of earnings & Government \\
\hline
\end{tabular}

\subsection{Sweden}

Sweden, as one of the representatives of the Nordic countries, has been recognized as the country with the most complete and gender-equal policies on parental leaves. As early as 1974, Sweden established a series of family benefits, turned the original maternity leave program into the "parental insurance" program, becoming the first country in the world to extend parental leave to fathers. In the next 40 years, Sweden has undergone many policy changes to promote fathers' participation in childcare. In 1995, the "daddy's day" policy established a one-month, specifically reserved for fathers, non-transferable parental leave for the first time, in order to protect fathers' rights to use the holiday [4].

The paid gender-neutral parental leave policy in Sweden is characterized by a longer duration of length, a higher proportion of ensured payments, a flexible leave system and the generous support of the government for this parenting benefit system. Research shows that Sweden spends more than $3 \%$ of its GDP on childcare benefits, even to be one of the highest in the EU. In addition to generous financial subsidies and flexible vacation time, the Swedish government has also established highquality public childcare services to alleviate family birth pressure. In recent years, nearly $90 \%$ of Swedish fathers have taken parental leave, making Sweden one of the countries with the smallest gender gaps in the world [5].

\subsection{The United States}

Different from European countries, the US government implements a series of family policies cooperated by the federal government, state governments, enterprises, and other social institutions. Instead of providing a direct policy of paid parental leave for fathers, the US government encouraged informal and private consultation to solve the public issue of childbearing so far. In 1993, the federal government passed the Family and Medical Leave Act (FMLA), enabling each eligible parent to have up to 12 weeks of unpaid parental leave within the first year after giving birth to a child, however, with no special incentives for fathers to take the leave. In the 2000s, Paid Family Leave (PFL) policy provided by state governments was successively implemented in six states and regions, including California, Hawaii, New Jersey, New York, Rhode Island and Puerto Rico. The financial support comes entirely from the payment of employees, which is part of the salary of employees [4].

The series of parental leave policies in the United States has the characteristics of great regional differences, the shortest duration time, comparably much lower financial support, and the lowest degree of government support and so on. However, the implementation of the Early Childhood Education and Care (ECEC) policy, which is led by the government, makes up for the deficiency of family parenting policy in the United 
States to some extent. By providing ECEC services to newborn families, and financial subsidies to social institutions that undertake ECEC services, the United States government takes up part of the child-rearing responsibility, relieving the pressure on families to raise children [2].

\subsection{Japan}

As one of the countries with the lowest fertility rate in the world, Japan has put forward a series of parenting support policies to cope with the severe trend of lower fertility and aging since the 1990s. Among them, the supplementary proposal for "Reacting Low Fertility in Japan" issued in 2002 emphasized for the first time the "re-evaluation of the role of men in parenting", proposed a genderneutral parental leave policy, and encouraged fathers to participate in left by extending the length of the leave [4].

The Japanese government has implemented the most generous parental leave policy in the world, which is characterized by the longest duration time and a high financial subsidy rate. The Japanese policy enables the parents to share up to one year of paid parental leave within one year of the child's birth. However, despite the strong economic support given by the government, since the policy is not enforced, it is impeded by the deep-rooted stereotypes of "women as family caregivers while men as breadwinners" in Japanese society and the traditional model of gender division of labor. In the process of implementation, the policy is often hindered by employers. Male employees in private enterprises often give up their right to leave under pressure from their employers. At the same time, due to the larger gender gaps in the Japanese job market, the wage difference between men and women is more significant [6]. Therefore, the vast majority of families would also grant the leave benefit to women, thus aggravating the gender gaps in the job market.

\subsection{China}

So far, China has not issued any parenting policy that is corresponding to the parental leave in other countries. Only 26 regions in China have stipulated local policies, including reserved full-pay "male nursing leave" or "spouse nursing leave" specifically for fathers. The paternity leave is generally short, ranging from 20 days to 7 days in most provinces and cities, with a maximum of 30 days in a few areas.
According to a survey conducted by the Women's Research Center of the Central Party School in 2006 , nearly $92.2 \%$ of the respondents basically agreed with the view that "parental leave is also a male's right." In addition, some authoritative media published surveys on social media show that more than $90 \%$ of people need parental leave from their fathers. This reflects the necessity for China to formulate a parental leave policy exclusively for fathers [7].

\section{FEASIBILITY ANALYSIS OF GENDER-NEUTRAL OR FATHER- SPECIFIC PARENTAL LEAVE POLICY IN CHINA}

The main purpose of implementing the genderneutral or father-specific family support policy is to promote gender equality, so as to solve the problem of low fertility which is universally faced by most high-income countries. In this sense, the proportion of fathers of parental leave applicants is used as the most intuitive assessment factor of the level of gender equality. At the same time, the employment situation of women and the changes of national fertility rates can also reflect the effectiveness of national fertility support policies to a certain extent ("Table 2"). According to OECD Family Database [3], the percentage of Swedish fathers involved in raising children is much higher, the gender gap in employment is relatively small, and the fertility rate has been stable in the past few years. In contrast, the United States and Japan do not have an exclusive leave policy for fathers, and the proportion of men applying for parental leave is low. The female employment rate is only close to the OECD average, but the rate still lags behind the average of EU countries. What is more, due to the imperfect implementation of family support policies and the social and cultural factors in Japan, the fertility rate in Japan has continued to decline in recent years. 
Table 2. The effectiveness of national fertility support policies in Sweden, US, Japan and China

\begin{tabular}{|c|c|c|c|c|c|c|c|}
\hline \multirow[t]{2}{*}{ Country } & \multicolumn{4}{|c|}{$\begin{array}{l}\text { The male participation in Employment rates for women (15-64 years old) } \\
\text { gender-neutral parental leave with at least one child aged } 0-14(\%)\end{array}$} & \multicolumn{3}{|c|}{ Total Fertility Rate(TFR) } \\
\hline & application & Total Rate & Part-time & Full-time & 1970 & 1995 & 2019 \\
\hline Sweden & $\begin{array}{l}\text { - In } 2018 \text {, fathers took about } 29 \\
\text { per cent of all Parental leave } \\
\text { days used in that year; } \\
\text { - The percentage of couples that } \\
\text { are sharing Parental leave } \\
\text { equally increases from } 40 \% \text { to } \\
60 \% \text {. }\end{array}$ & 86.1 & 8.5 & 76.7 & 1.94 & 1.74 & 1.70 \\
\hline The United States & $\begin{array}{l}87 \% \text { of women and } 59 \% \text { of } \\
\text { men use at least half of the paid } \\
\text { Parental/family leave } \\
66 \% \text { of women and } 36 \% \text { of } \\
\text { men use all available paid leave }\end{array}$ & 70.0 & 11.5 & 58.1 & 2.46 & 1.98 & 1.71 \\
\hline Japan & $\begin{array}{l}\text { In } 2018,6.16 \% \text { of male } \\
\text { workers had started or applied } \\
\text { for Parental leave; } \\
\text { - More than } 80 \% \text { took less than } \\
\text { one month of leave, and } 36.3 \% \\
\text { took under five days. }\end{array}$ & 70.6 & 1 & 1 & 2.13 & 1.42 & 1.36 \\
\hline China & 1 & 59.8 & 1 & 1 & 5.73 & 1.66 & 1.70 \\
\hline OECD average & 1 & 70.9 & 17.9 & 52.6 & 2.84 & 1.77 & 1.60 \\
\hline EU average & I & 73.0 & 13.6 & 58.3 & 2.37 & 1.51 & 1.52 \\
\hline
\end{tabular}

When it comes to the feasibility analysis of implementing father-specific parental leave policy in China, three main dimensions, including "the source and the cost of financial support", "the policy availability to fathers", and "the necessity of other cooperating child care supporting policies", should be taken into special consideration based on the previous policy comparison between Sweden, the US, and Japan.

\subsection{The Source and the Cost of Financial Support}

As a high-welfare state, Sweden can implement a comprehensive reproductive support policy mainly because the government spends more than $3 \%$ of its GDP on childcare benefits. According to International Labor Organization (ILO), based on its cost estimation in 12 Asian and African countries, the cost of the minimum basic health care plan in 2010 in these countries is equivalent to $1.5 \%$ to $5.5 \%$ of the GDP of each country. In the broader social security system, including pensions, health care, children's allowances, and social assistance / employment schemes (non- childbearing), administrative costs consume $3.7 \%$ to $10.1 \%$ of the gross domestic product of these countries. Therefore, if the parental leave expenditure is all supported by the government, it may bring a considerable financial burden to the government [8].

For China, it is more feasible to refer to the family policy scheme in the United States. In addition to the financial subsidies from the government, employers and employees should also bear a certain proportion of the expenditure to reduce the financial burden of the government. The experience from the practice in the United States also shows that there has been a deep gap in the proportion of parental leave applicants between employees in state-owned enterprises and those in private enterprises. If more enterprises can take up the social responsibility, the benefits gap between the employees of state-owned enterprises and those of private enterprises will also be reduced to make a difference. 


\subsection{The Policy Availability to Fathers}

According to the data in the table above, the US and Japan have a lower proportion of father applicants for parental leaves and lower employment rates for women, which means that the gender-neutral parental leave policy in the US and Japan might have not played a significant role in dealing with gender inequality in the job fields. Despite the encouragement in fathers' involvement in child care, the governments set up no specific leave policies reserved for fathers, leading to the failure of ensuring males' right of parental leave applications.

For the purpose of ensuring the effectiveness of the policy, China should mainly follow the example of Sweden, stipulating that fathers must take a certain proportion of holidays. At the same time, China should also take the practice in Japan as a warning. Since China and Japan are both East Asian countries, which have similar social customs, cultural backgrounds and gender concepts, China should put focus on gender balance in this policy. In China and Japan, men often play the role of "family breadwinner" in the division of labor. Therefore, men are also prohibited from participating in family affairs and taking care of children, which has always been considered the responsibility of women in any work. Although the change of gender concept "does not roll in on the wheels of inevitability", the protection of fathers' right for paid parental leave and the establishment of non-transferable, the father-specific parenting policy can accelerate the process of gender equality.

\subsection{The Necessity of Other Cooperating Child Care Supporting Policies}

Although Japan has adopted the most generous parental leave policy in the world, it still has an extremely low fertility rate, which is not only impeded by the stereotypical social customs, but also the lack of complete supporting policies for family plans. The five-year Plan for Emergency Care Countermeasures, promulgated by the Japan Government in 1995, called for support for child care by improving the number and quality of care institutions. However, due to the deficiency in effective management mechanisms, the target completion rate of the plan was much lower than expected by 1999. Therefore, in addition to the most direct parental leave policy, China should still learn from the United States and Sweden ECEC policies to set up more "high-quality but less expensive" social care institutions and other government-supported policies to reduce the childrearing burden on families and individuals.

At present, although there are nearly 3000 registered enterprises of childcare institutions in China, most of the existing institutions are of "uneven quality", or of "high quality with expensive", because of the lack of official organization and policy support. As a result, excellent childcare resources are only limited to a small number of children from the middle class family and above in big cities, aggravating the gap between the rich and the poor, as well as the gap between cities and countries. A governmentsupported cooperating child care policy in China is also necessarily needed to change the current situation.

\section{CONCLUSION}

This study compares the status and development of father-exclusive and gender-neutral parental leave policies in Sweden, the United States, Japan, and China. By analyzing the employment and fertility data of professional women in these countries, the feasibility of implementing relevant policies in China has been deeply explored. This study confirmed that China should "remove the dross of other countries and take the essence of them" by strengthening the role of the government in promoting family policy of gender equality. In addition to direct financial supporting policies, the government should pool more resources on building cooperating child care welfare institutions and other instruments. What's more, the government should also encourage the participation of social enterprises to help share the social responsibility of parenting and reduce the burden of career women. Most importantly, in order to ensure the effectiveness of the policy, the policy should emphasize fathers' participation in parenting, and reverse the false gender stereotype and promote gender equality in China.

However, there are still some problems in this research that need further discussion. As there has been no father-specific parental leave policy in China before, the discussion in this research is still at a relatively general level. Without any certain data support, no specific quantitative analysis of the effectiveness of the policy is conducted in previous researches. After the implementation of the pilot policy in the future, regression discontinuity design and other methods can be introduced to evaluate the effectiveness of the policy. Besides, due to the 
uneven distribution of living conditions in different regions in China, more localized adjustments should be made to adapt to the local situations. More efforts will always be paid on this issue to make a difference.

\section{AUTHORS' CONTRIBUTIONS}

This paper is independently completed by Xiwen Huang.

\section{REFERENCES}

[1] China National Bureau of Statistics. (2020). National Annual Statistical Bulletin [EB/OL]. [2020-05-11].

http//www.stats.gov.cn/tjsj/tjgb/ndtjgb/.

[2] RUDY RAY SEWARD, DALE E. YEATTS \& LISA K. ZOTTARELLI. (2002).Parental Leave and Father Involvement in Child Care: Sweden and the United States. Journal of Comparative Family Studies, 33(03): 387-399.

[3] OECD Family Database [Z/OL]. [2020-06-08]. http://www.oecd.org/els/family/database.htm.

[4] Koslowski, Alison \& Blum, Sonja \& Dobrotić, Ivana \& Kaufman, Gayle \& Moss, Peter. (2020). 16th International Review of Leave Policies and Related Research 2020.

[5] FANG Lijie, CHEN Huiling. (2021). Balancing Work-Life: Comparative Study of Family Policies in Different Countries. Population Journal, 43(02), 86-97.

[6] Wang Xin. (2007). On the Supportive Policy of Bringing Up Children in Japan and the Inspirations. Early Childhood Education (Educational Sciences). 355, 48-51.

[7] Li Huiying, LIU Cheng. (2020). Exploration of the Difficulties in Advocating Parental Leave in China. Journal of China Women's University. 02,53-58.

[8] Lin Yanling. (2018). A Study on Foreign Maternity Protection Leave System. Journal of China University of Labor Relations, 32(06), 10-30. 